\title{
An Analysis of Social Proverbs from the Perspective of Cultural Semiotics
}

\author{
Wen Zhao \\ Faculty of English, College of Literature and Law, Sichuan Agricultural University, Ya'an, China \\ Email: ivanmotoz@yahoo.com.cn
}

\begin{abstract}
Social proverbs contain life philosophies and experience as well as moral standards; aspects of social life are reflected in the mirror of social proverbs. Social proverbs are of both language and culture. Because of their abundant cultural information, social proverbs have been studied from the point of culture in many researches. Modern semiotics has been widely applied to cultural studies as an effective approach whose theories and methods can be generally and successfully used to interpret the meaning process of various social-cultural phenomena. Bakhtinian semiotic theory seizes a crucial position in Russian semiotics which features the cultural tradition. Because of the purpose of this paper to study the relation of social proverbs to culture, Bakhtinian semiotic theory mainly coping with such issues as the essence of utterances and the functions of ideological signs is chose as the major analytic tool of this study. Bakhtin Circle takes the utterance as the typical ideological sign. Social proverbs are special utterances and can therefore function as ideological signs. Ideology in Bakhtin Circle is the totality of reflection and refraction of natural and social reality in the human brain, which is greatly influenced by such cultural patterns as world views, belief and value systems which originate from the deep structure of culture. Ideological signs actually contain the content of the deep structure. The deep structure is the core of culture. In this sense, ideological signs are cultural signs. Social proverbs show a direct link with the deep structure; many conceptions composing the latter are revealed in them. Consciousness takes shape in the material of ideological signs. The deep structure, taking form of social proverbs, penetrates into the consciousnesses and shape individual mind; abstract cultural concepts are transformed into concrete perception and behaviour so that culture can endure.
\end{abstract}

Index Terms - social proverbs, cultural signs, Bakhtinian semiotic theory

\section{INTRODUCTION}

"Proverbs bear age, and he who would do well may view himself in them as in looking glass." This proverb itself perfectly demonstrates the essence of the proverb; it preserves the wisdom of humankind throughout generations and serves as a guide to acceptable behaviour.

Joanna Wilson (1982), in the preface of The Oxford Dictionary of English Proverbs, says that proverbs may date "probably from the time when the wisdom and percept were transmitted by story and song" (p. v). Experience and knowledge gained in life and production by ancestors used to spread without the help of written language. Therefore, proverbs, as compressed expressions easy to memorize, emerged. Nowadays, proverbs may confront general rejection and deteriorate into vulgar sayings, but "every day we still hear proverbs, many of ancient origin, many transmitted in print, many debased to clichés..." (ibid). Proverbs, still winning popularity, form a linguistic and cultural phenomenon which can not be ignored.

The use of proverbs is centuries old. They have undergone changes of human societies but maintained the core of culture. As Larry A. Samovar, Richard E. Porter and Lisa A. Stefani (2000) suppose in Communication between Cultures, cultures can be learned through proverbs (p. 39); they are culture-loaded expressions. This study focuses on the cultural dimension of the proverb.

\section{LITERATURE REVIEW}

\section{A. Definitions of the Proverb}

With the structure, content, purpose and other characteristics so varied, proverbs do not form a categorized genre with distinctive features and clear boundary. Thus, defining the term "proverb" seems an insurmountable task for either common people or scholars. Although the task of defining the proverb is tough, scholars, from ancient times to nowadays, take constant effort to fulfill it. Early Greek scholars including Plato and Aristotle in particular wrestled with the question of what constitutes a proverb. According to Mieder (1989), Aristotle might be the first one in the West to give a concise definition that expresses the essential aspects of the proverb. In his description of metaphor in Book 3, Rhetoric, Aristotle (2005) defines proverbs as "metaphors from one species to another" (p. 141). Actually, some folk adages using metaphor and simile to describe events or matters are also contained in the category of proverbs which has a broader territory before the $18^{\text {th }}$ century. (Simpson \& Speake, 2001)

As a master proverb researcher, Archer Taylor used an entire book—his famous classic study Proverbs - to define the 
proverb, and he finally reached a conclusion proverbial itself:

The definition of a proverb is too difficult to repay the undertaking.... An incommunicable quality tells us this sentence is proverbial and that one is not. Hence no definition will enable us to identify positively a sentence as proverbial...Let us be content with recognition that a proverb is a saying current among the folk.

(qtd. in Mieder, 1989, p. 14)

So many scholars afterwards agreed and cited Taylor's statement of the impossibility of defining proverb precisely when dealing with the definition problem.

After Taylor's proverb definition and others with resemblance by taking proverbs as carriers of truths, wisdom, experience and common sense, especially after the founding of modern linguistics, scholars gave more and more complex definitions of the proverb to "unlock the secrets of "proverbiality" (ibid).

Major authoritative English dictionaries all provide definitions of the proverb, which to some extent vary from each other but also share some similarities. According to Webster's Dictionary of the English Language Unabridged (1979), a proverb is "a short saying in common use expressing a well-known truth or common fact ascertained by experience or observation; a maxim; an adage." The definition in Longman Modern English Dictionary (1976) gives more details on the content of the proverb, a proverb is "a brief familiar maxim of folk wisdom, usually compressed in form, often involving bold image and frequently a jingle that catches the memory".

\section{B. Typology of Proverbs}

The typologies of proverbs like definitions of the proverb, vary from different angles. This paper aims to study proverbs mainly from cultural perspective, so the classification by Wen Duanzheng is adopted. Wen (2005) classifies proverbs in terms of their contents or subjects; comparing with other typologies, this one is comprehensive:

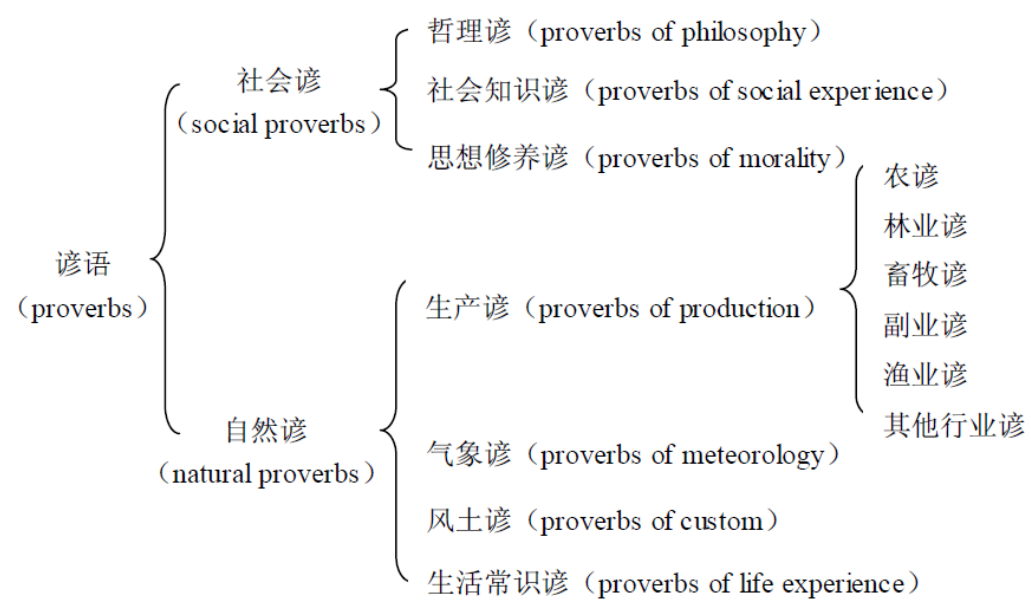

Wen Duanzheng classifies proverbs into two major categories: Natural proverbs contain experience of production and relevant knowledge about production, e.g. “犁地要深, 耙地要平”. Social proverbs are about social life of people. They can be further categorized into proverbs reflecting philosophical thoughts, e.g. “无风不起浪”, proverbs preserving social experience, e.g. “言多必失”, proverbs serving to strengthen morality, e.g. “宁伸扶人手, 莫开陷人口”. (ibid, p. 36-49) This paper focuses on social proverbs.

\section{THEORETICAL FOUNDATION}

The majority of Bakhtinian thoughts on the sign are expressed in Marxism and the Philosophy of Language with the signature of V. N. Voloshinov, and other parts in essays such as "Towards a Methodology of the Human Science". Recent archival researches suggest that Marxism and the Philosophy of Language by Voloshinov is largely or even totally created by Bakhtin, because "Voloshinov's work on language was based on intellectual sources quite distinct from those of the early Bakhtin" (Bostad et al., 2004, p. 5). "Clark and Holquist's impressive biography of Bakhtin" assumes that "the works of Voloshinov and Medvedev were actually written by Bakhtin himself" and "the Marxism advocated therein being mere "window dressing' to secure publication". (ibid, p. 4) Some more detailed evidences can support the assumption above, e.g. the hostility towards structuralist linguistics, the insistence on the interactive character of individual consciousnesses in society with language as a shared medium, etc. However, Voloshinov's own analysis of verbal interaction was accepted by Bakhtin and combined with the latter's ideas of intersubjectivity so that the social-institutional force within the linguistic medium were considered to study the interaction among individual consciousnesses. (ibid, p. 5-6) Therefore, "Bakhtinian" instead of "Bakhtin's" is used in this study to stress Bakhtin's determinative influence on this semiotic theory, which is of Bakhtinian style, without ignoring the contributions by other colleagues in Bakhtin Circle.

The semiotic thoughts of Bakhtin Circle are summarized by scholars afterwards; "Bakhtin Circle semiology" is even 
used to name this incomplete set of theories. To be prudent, such terms as semiotics or semiology are avoided in this paper to refer to Bakhtinian theory on signs; instead, it is considered as a theory or a mode of a particular school. Because the theory is concerned with the realization of signs in social context as well as the reflection or refraction of ideological signs to social reality, it is taken as of cultural semiotics according to the typological criteria by Li Youzheng(2007).

\section{A. Bakhtinian Theory on Sign, Ideology and Consciousness}

Bakhtin supposes that signs are created among individuals associated in society to serve their interactions; objects that signs refer to are contained within particular areas which attract attention of the society in certain periods and need to be emphasized. Signs only emerge in the process of interaction among individuals. (Voloshinov, 1986) Bakhtin puts emphasis on the social nature of the sign; he thinks that the sign is created based on the society and for the need of interaction in the society. The premise of the emergence of the sign is the existence of something that men want to exchange their ideas.

The secure link between the sign and ideology is highlighted in Bakhtinian theory of semiotics. In Marxism and the Philosophy of Language, Bakhtin Circle claims that "the domain of ideology coincides with the domain of signs...everything ideological possesses semiotic value." (Voloshinov, 1986, p. 10) There is no ideology without signs. Everything ideological attains a meaning; it reflects or stands for something else, that is to say, it is a sign.

Ideological signs are not only shadows or reflections of reality but themselves material segment of reality. "Every phenomenon functioning as an ideological sign has some kind of material embodiment...a sign is a phenomenon of the external world." (ibid, p. 11) Bakhtin Circle emphasizes that "signs are partly material...but in no way does it follow the materiality that signs are 'things' in the normal sense", why signs being taken as material objects is that as so they can be "assigned their function as signs by their specific, but recurrent connection with human beings". (Bostad, et al., 2004, p. 9) The reality of the sign lies in the fact that the sign is also the phenomenon of the outer world which people can observe, perceive and treat as an object.

Ideological signs do not always reflect the reality faithfully, they also refract the reality. (Voloshinov, 1986) It may distort the truth. Differently oriented accents intersecting in every ideological sign is the cause for the refraction. (ibid) The term "accent" in Bakhtin Circle refers to every distinct voice from groups or individuals. Accents, no matter dominant or recessive, affect and interact with each other to make ideological signs dynamic and developing, although the ruling class spares no effort to stop the social multiaccentuality to make signs stable or even permanent.

Though Bakhtin Circle stresses the material character of the sign, the connection between the signifier and the signified is actually at the heart of the theory. Taking the sign and ideology together into consideration implies the close link of the sign to human mind in Bakhtinian semiotic theory. Ideology is a fundamental but complex concept in cultural studies. It is commonly used to refer to a more or less coherent set of beliefs. (Edgar \& Sedgwick, 2008, p. 171) The term "ideology" is coined in the eighteenth century by the French philosopher Destutt de Tracy to denote the science of ideas; but it becomes popular and important with Marx. In Marxist sense, ideology is related with class struggle and political interests. Bakhtinian view on ideology, according to Lachmann (2004), is different from those of traditional Marxists but assumes that ideologies or world views are something "inherent in any semiotic system" (p. 74). Bakhtin Circle sees ideology as a social phenomenon. According to Bakhtin Circle, ideology is the whole totality of reflections and refractions in the human brain of social and natural reality, as it is expressed and fixed by man in word, drawing, diagram or other form of sign. (Voloshinov, 1986) Obscure the definition is, the mental nature of ideology in Bakhtin Circle is obvious. Ideological signs in Bakhtinian semiotic theory are foremost signs about human mind.

Saussure believes that the connection between the signifier and the signified of the linguistic sign lies in the convention; however, he chiefly deals with the form or structure of the signifier rather than the connection. Bakhtinian semiotic theory develops Saussure's assumption into a more detailed one by studying how the signifier reflecting or refracting the signified. Different accents in society collectively determine the connection between the signifier and the signified of an ideological sign.

Bakhtin Circle insists that "consciousness itself can arise and become a viable fact only in the material embodiment of signs" (Voloshinov, 1986, p. 11). Consciousness becomes consciousness only when being filled with ideological signs and only in the process of social interaction. By means of interactions among individuals as social members, the content of signs eventually becomes the content of individual consciousnesses:

Consciousness takes shape and being in the material of signs created by an organized group in the process of its social intercourse. The individual consciousness is nurtured on signs; it derives its growth from them; it reflects their logic and laws. The logic of consciousness is the logic of ideological communication, of the semiotic interaction of a social group. (ibid, p. 13)

Ideology of Bakhtin Circle is the totality of reflections and refractions in human mind of social and natural reality. Thus, individual consciousnesses are essentially composed of those reflections and refraction carried by signs. The refraction is caused by arguments among accents, the accents, borne by signs, enter and echo in individual consciousnesses. In this sense, individual consciousness is a social-ideological fact. However, individual consciousnesses can affect ideologies in turn. Only when ideological signs enter individual consciousnesses, they become real signs which can be communicated and understood.

Bakhtinian theory of individual consciousnesses and ideologies combine Saussure's and Peirce's models of the sign. 
Saussure, highlighting the signs as a part of social life, supposes the conventional nature of the connection between the signifier and the signified; while Peirce emphasizes the formation of the connection as a psychological process in individual mind. In a word, the nature of the sign in Saussure is social but in Peirce is individual. In Bakhtinian semiotic theory, individual consciousnesses are containers of signs of social ideologies; signs, created by individuals to satisfy the need of social interaction, in turn convey ideologies shared within society to individual consciousnesses and help to form them. The conventional nature of signs is the result of interactions among individuals in society, and the psychological process to understand or create a sign, because of its operation in the consciousness, is inevitably affected by pre-existed social ideologies. No matter social or individual, they are two sides of the nature of the sign; one depends on the other for existence.

\section{B. Bakhtinian Theory on Sign and Utterance}

In Bakhtin Circle, the utterance is the basic unit of the "concrete reality of language" (Voloshinov, 1986, p. 93); it covers all forms of language uses from written texts to spoken words. According to Bakhtinian semiotic theory, the utterance is both dialogic and social. (Edgar \& Sedgwick, 2008, p. 373) By dialogic, it means an utterance is an element in a "continuous process of verbal communication" (Voloshinov, 1986, p. 95); by social, it indicates that an utterance is determined, oriented and situated socially. The dialogic and social characters of the utterance overlap with each other; only the utterance dialogic in essence can be affected by social ideological factors.

The utterance, as being dialogic, is oriented to an addressee; the addressee can be presupposes as a representative of a social group rather than an actual person. (ibid, p. 85) In Bakhtianian semiotic theory, the utterance is theorized as a reciprocal product co-authored equally by addresser and addressee. (ibid, p. 86)

Utterances prevail society and are connected with their surrounding social milieus; wherever there is an interaction or communication there must be utterances. Only in interactions among members of society can an utterance carry out its functions well.

The utterance reflects or refracts natural or social reality through its verbalized components. Thus, the utterance stands for something else, i.e. it is a sign. The reality of utterance entirely lies in its essence as a sign. Moreover, it is a typical ideological sign, as it is filled with ideological content of every aspect of society. As a sign, the utterance perfectly performs its ideological functions. Many ideological signs have been specialized for some particular areas, but utterances can satisfy any ideological requirement. They accompany ideological conduct from creation to perception.

\section{Social Proverbs as Cultural Signs}

\section{A. The Mechanism of Social Proverbs as Cultural Signs}

Social proverbs reveal the social dimension of culture and contain wisdom for the masses to conduct in accordance to the requirements of the society.

1. Social Proverbs as Ideological Signs

The reality of language consists of utterances. Any language use, spoken or written, can be taken as an utterance. According to this conclusion, utterances belong to parole rather than langue.

Social proverbs are fixed sentence-level idiomatic expressions; they form a unique part of lexicon. In this sense, they should be considered as a part of langue. However, by analyzing the definitions and examples, the essence of utterance can also be found in social proverbs.

First, social proverbs come from language uses and still function so. Proverbs are mainly of folk origin; they come from common people's daily talks and get the proverbiality through oral transmission. Moreover, the completeness of a proverb as a statement allows it the possibility and convenience to function a language use. Thus, comparing with other elements of lexicon such as words and set phrases which primarily serve to construct language uses, proverbs themselves are complete language uses. For example, “有钱能使鬼推磨” and “money makes the mare go” are directly and generally quoted in people's conversations as complete language uses without major alternations.

Second, as any other utterances, a social proverb is oriented towards an addressee. In Bakhtinian theory, the "addressee" needs not to be an actual person but can stand for a social group. The utterance is created by its addresser in the attempt to exert his influence on some individual or group; this attempt also helps to form the utterance. This feature is perfectly revealed in proverbs. Proverbs, either from the general public or classics, are for and towards common people. They convey ideologies, views on society and nature, to the broader masses. The colloquial characteristic of proverbs is one of the results of their creators' efforts to affect the public perception. The proverbs “力微休负重, 言轻 莫劝人” and “eat leeks in lide, and ramsons in may and all the year after physicians may play" contain folk wisdom on some social and nature reality and transmit it by means of colloquial expressions.

Last but not least, social proverbs are closely linked to social milieus and therefore determined and situated socially. Social feature is one of the utterance's crucial essence. Every utterance is formed in a social context and as a result bears its mark. On proverbs, especially social proverbs, the brand of society is obvious. In such social proverbs as “万般 皆下品, 惟有读书高” and “百业农为本”, the link to their social surroundings is apparent.

In conclusion, by owning close relation to language uses and being towards addressees, social proverbs fulfill the primary need of the utterance as being dialogic; obviously influenced by society, social proverbs attain the feature of the 
utterance as being social. Thus, social proverbs, to a certain extent, can be regarded as utterances. According to Bakhtinian semiotic theory, an utterance is a typical ideological sign, so social proverbs can as well function as ideological signs.

2. Ideology and the Deep Structure of Culture

a. Defining Culture

Generally speaking, definitions of culture can be categorized into two groups: definitions in the narrow sense and that in the broad sense. Culture in the narrow sense, also called culture with a small "c", contains only intellectual and spiritual creations including customs, laws, achievements in arts and science, etc. The definition of culture given by British anthropologist Edward B. Taylor belongs to this group. In Primitive Culture: Researches into the Development of Mythology, Philosophy, Religion, Language, Art, and Custom, Tylor (2005) defines culture as a complex entity comprising knowledge, beliefs, art, morals, laws, customs and any other capabilities and habits acquired by men as members of society. The early definitions of culture are for most of this kind. Culture in the broad sense, called Culture with a capital "C", is an all-embracing concept; it can refer to both spiritual and material things created by human beings. The descriptive definition proposed by D. G. Bates and F. Plog (1990) is of this kind and contains the major territory of culture, "Culture is a system of shared beliefs, values, customs, behaviors, and artifacts that the members of a society use to cope with their world and with one another, and that are transmitted from generation to generation through learning" (p. 28).

b. The Deep Structure as the Core of Culture

According to Samovar et al. (2000), the deep structure of culture refers to such issues as the relation between God and man, the individual and the group, among families, as well as differing views of the relative importance of liberty and authority, equality and hierarchy, rights and responsibilities. Those issues together construct the deep structure of culture, which endures for centuries and helps define the certain culture.

In the deep structure can each culture find the source for its unique way to view the world. "World view is a culture's orientation toward God, humanity... and other philosophical issues that influence how its members perceive their world." (ibid, p. 88) It deals the questions about the meaning of life and man's existence. The world view originates in the deep structure of culture and lies at the heart of the cultural system. It can influence all aspects of perception. (ibid)

As the central cultural element, the world view consequently affects cultural belief and value systems. Belief systems are people's beliefs to truth; they tell people how the world operates. (ibid, p. 58) Based on belief systems, value systems can be formed. A value can be defined as "an enduring belief that a specific mode of conduct or end-state of existence is personally or socially preferable to another." (Rokeach, 1973, p. 5) A value system is "a learned organization of rules for making choices and for resolving conflicts." (ibid, p. 161) It is a set of criteria to judge behaviour, which represents people's requirements, expectation, and prohibition. Any culture, although with different individual beliefs and values, contains cultural ones permeating the entire milieu. Belief and value systems, together with other patterns including norms, attitudes, etc of a culture influence its members' perception of reality and finally shape their behaviour - their reaction to the world.

Based on the presentation above, a diagram of cultural system can be drawn as follows:

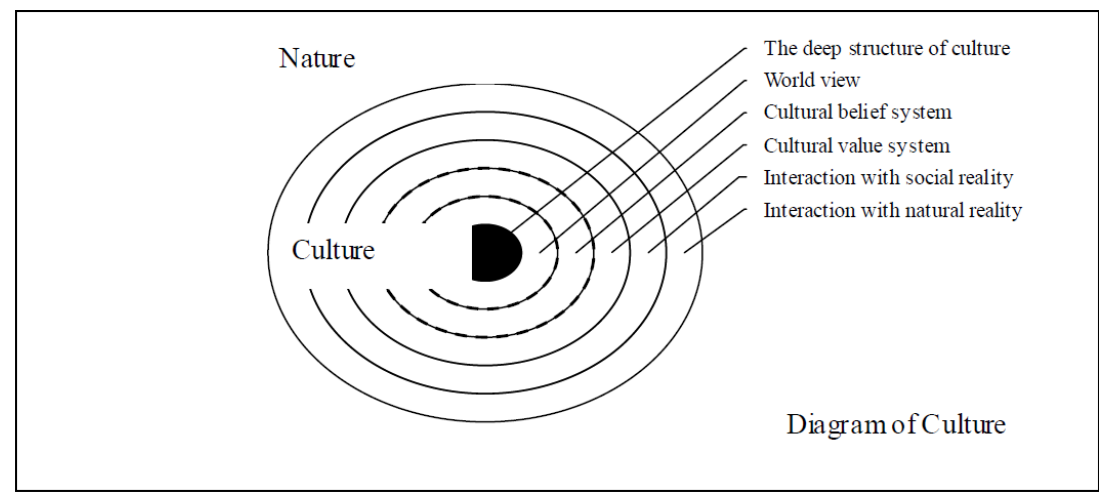

In this diagram, the part outside the circle of culture is nature. The part of nature can be considered as the background of culture, because culture is built on the basis of nature. The cultivation of nature is the foundation of culture; when human beings surpass their natural inheritance, culture begins. Nature is in contrast with culture; the latter is the world created by man.

The circle of culture contains three main layers: The innermost layer can be further divided into four sub layers, which are the deep structure of culture, the world view, cultural belief and value systems from inner to outer. Dotted lines are used here as the dividing line of them. As the author of the thesis has presented, the relation of the inner ones like the world view to the outer ones like beliefs are kind of determination. The deep structure, as the source of those outer layers, is used a black solid circle to indicate, which implies its stability and decisive force as the core of culture. The innermost layer of culture determines people's perception and behaviour to reality. The layer in middle is that of man's interaction with social reality, the result of which contains the patterns of behaviour including customs, laws, and 
etc. The outermost one is the layer of humankind's interaction with natural reality. Artifacts such as tools, constructions, works of art as well as skills and techniques handed down throughout generations to make artifacts are all results of man's direct interaction with natural reality.

From outer to inner, elements of culture is becoming more stable. The outermost part of artifacts changes dramatically due to the development of science and technology and the middle layer of behaviour is also dynamic because of the never-ending social activities, while the deep structure is enduring.

Ideology in Bakhtinian Circle is "the whole totality of reflections and refractions in the human brain of social and natural reality". That is to say, ideology is the collective perception of the outside world. According to the previous analysis, human perception is greatly affected by such cultural patterns as world views, belief and value systems which are closely connected to the deep structure of culture. Thus, it is justifiable to say that Bakhtinian ideology, nearly equaling the innermost layer of culture about human mentality, is originated from the deep structure of culture; the content of ideology can find its root in the deep structure. Ideological signs in Bahtinian semiotic theory, bearing ideologies of culture, in essence reflect or refract the deep structure of culture.

The deep structure is the core of culture; it is its most essential and stable part. Other elements of culture at outer layers are determined by and originated from this deep structure. The whole cultural system is in essence a broader projection of its deep structure. In this sense, ideological signs, functioning as carriers of the deep structure of culture, actually convey the information related to the overall culture. As utterances, social proverbs are typical ideological signs and then carriers of the content of the deep structure of culture. Components ranging from artifacts to customs are all linked with cultural information revealed by social proverbs. Social proverbs, therefore, can be taken as cultural signs.

\section{B. The Functions of Social Proverbs as Cultural Signs}

As argued in the preceding sections, social proverbs can be taken as ideological signs or cultural signs. According to Bakhin Circle, ideological signs reflect or refract the natural and social reality and preserve social ideologies, which as the author of the paper just pointed out directly originate from the deep structure of culture. Social proverbs, as ideological signs and with the ideological content, reflect or refract the deep structure of culture and help shape individual consciousnesses.

1. Social Proverbs Reflecting or Refracting the Deep Structure of Culture

Bakhtin Circle points out that signs are created among members of society to meet their need of interaction. Signs are used to talk about their common interest. Also only in interactions can utterances carry out the ideological functions successfully and completely. Social proverbs mainly comprise those of life philosophy, morality, as well as social experience. People, as long as they live in a society, have to face and deal with those issues and are willing to share on them their thoughts and feelings. Social proverbs, bearing folk wisdom handed down from ancestors about social life, are convenient and effective tools for communication relevant to those topics.

As presented in the preceding sections, the ideology in Bakhtin Circle reflects or refracts natural and social reality; the reality transforms into the subjective reality during the perception influenced by cultural patterns. Among those cultural patterns, world views as well as belief and value systems closely originated from the deep structure of culture wield decisive influence. These crucial cultural patterns can be generally found in social proverbs.

The world view on such issues as God and men, life and death, individual and group, parents and children, equality and hierarchy etc. are straight reflected or indirectly refracted in social proverbs, for example:

God is above all.

生死有命, 富贵在天。

Better bend than break.

好死不如赖活着。

If you want a thing well done, do it yourself.

众人拾柴火焰高。

The sins of the fathers are visited upon the children.

父母之命, 媒妁之言。

Jack is as good as his master.

小鬼斗不过阎罗王。

Originated from the world view, cultural belief and value systems also present themselves in social proverbs to exert their influence on the masses:

God is where he was.

离地三尺有神灵。

Heaven's vengeance is slow but sure.

不是不报时候未到。

Do well and have well.

善有善报，恶有恶报。

多行不义必自毞。

Every one must carry his own cross. 
The philosophies or morality contained in social proverbs depending on which men conduct and the society operates lie at the heart of social life; they reveal the deep structure of culture. Comparing with other cultural phenomena, due to their close link with world views as well as cultural beliefs and values, the reflections or refraction in social proverbs are much more obvious.

2. Social Proverbs Influencing Consciousnesses

According to Bakhitinian theory on the connection between social ideologies and individual consciousnesses, consciousnesses arise only with the embodiment of ideological signs. Ideological signs emerging in the process of social interaction stand for the reality they may distort or be true to. The reflection or refraction of the reality, with signs as their vehicles, penetrates into individual minds and constructs the content of consciousnesses. Seeing that Bakhtinian semiotic theory points out, the content and logic of consciousnesses are essentially that of the social ideologies and semiotic interactions.

As discussed above, social proverbs are ideological signs and reflect or refract the deep structure of culture. By entering individual consciousnesses, social proverbs affect or even shape consciousnesses with world views, belief and value systems. As the result of the acceptance of these cultural patterns, the deep structure veiled in social proverbs, consciously or unconsciously, makes its way into consciousnesses and eventually influences individuals' perception and behaviour.

This may partially explain how culture, especially its deep structure, can endure and why through proverbs cultures can be learned. So long as individuals want to survive or succeed in the society, they have to interact with others, particularly on some crucial issues or fields, with the help of signs. Such cultural signs as social proverbs, through the use, gradually transmit their cultural information to both the users and the receivers. Moreover, this process may probably begin before we are aware of it. After penetrating into individual minds and form consciousnesses, the deep structure of culture, taking form of nearly every kind of cultural patterns, changes from abstract concepts into concrete subjective reality in brains. As the process that seems endless continues, a culture maintains.

This interdependence of culture, signs and consciousnesses are also exemplified in Sapir-Whorf hypothesis. Sapir-Whorf hypothesis has developed into two versions: the strong version, linguistic determinism, which holds that language determines manners of thought; the weak version, linguistic relativity. Some elements of language like proverbs for instance, are cultural signs which preserve the essential cultural information; thanks to their strong shaping force towards cognition and conduct as well as the wide use among language communities, the core component of culture is generally accepted by the members so that a culture, together with its distinct features, can exist and last.

\section{CONCLUSION}

In the attempt to shed light on the mechanism of social proverbs for establishing the connection to cultures and their functions as carriers of cultural message, the author turns to semiotics to seek help; from Bakhtinian semiotic theory has he borrowed the analytic tool.

The social proverb, with the form as a colloquial statement, the content of social common interest and the folk origin, can be taken as an utterance to great extent. As utterances, social proverbs have ideological utility as cultural signs in reflecting or refracting the deep structure of culture and influencing consciousnesses.

This study ends with following findings of significance:

Firstly, semiotics proves to be an effective approach to study language from the cultural viewpoint. Semiotics, with its plentiful theories to interpret linguistic phenomena as cultural ones and finally as signs, fulfills the requirements to deepen the understanding of the relationship between language and culture. Bakhitinian theory, among cultural semiotics, serves perfectly to comprehend the cultural aspects of some linguistic signs.

Secondly, the unique feature of social proverbs leads to their use as utterances. Utterances are typical ideological signs, social proverbs therefore can perform functions as cultural signs to maintain and transmit the deep structure of culture.

\section{SUGGESTIONS FOR FUtURE RESEARCH}

There are inevitably limitations and defects in this study; accordingly, some improvements should be made in further researches.

Bakhtianian semiotic theory is not a completed one with clear framework and precise definitions for those key items; contradictory interpretations are not unusual among the works applying this inspiring theory. Although the foundational theories of semiotics are introduced to interpret it, Bakhtinian theory of semiotics seems still obscure to some extent. Nevertheless, this semiotic theory, with reflective insights into the social and cultural essence of signs, is a buried treasure needing further exploitation.

Cultural semiotic theories other than Bakhtinian can be applied to study idiomatic expressions besides proverbs. The relationship between culture and language which has puzzled scholars for long time may be partially solved by fostering semiotic researches determinedly and profoundly.

\section{REFERENCES}


[1] Aristotle. (2004). Rhetoric (translated by Roberts W. R.). New York: Dover Publications.

[2] Bates, D. G. \& F. Plog. (1976). Cultural Anthropology ( $\left.3^{\text {rd }}\right)$. New York: McGraw-Hill.

[3] Bostad, F. et al. (eds.) (2004). Bakhtinian Perspectives on Language and Culture: Meaning in Language, Art, and New Media. Hampshire \& New York: Palgrave Macmillan.

[4] Chandler, D. (2002). Semiotics: The Basics. London \& New York: Routledge.

[5] Cohen, T. (1998). Ideology and Inscription: "Cultural Studies" after Benjamin, de Man, and Bakhtin. Cambridge \& New York: Cambridge University Press.

[6] Edgar, A. \& Sedgwick, P. (eds.) (2008). Cultural Theory: The Key Concepts $\left(2^{\text {nd }}\right)$. London \& New York: Routledge.

[7] Hofstede, G. (1991). Cultures and Organizations: Software of the Mind. London: McGraw-Hill.

[8] Honeck, R. P. (1997). A Proverb in Mind: A Cognitive Science of Proverbial Wit and Wisdom. New Jersey: Lawrence Erlbaum.

[9] Kramsch, C. (2000). Language and Culture. Shanghai: Shanghai Foreign Languages Education Press.

[10] Li, Youzheng. (2007). An Introduction to Theoretical Semiotics $\left(3^{\text {rd }}\right)$. Beijing: Renmin University of China Press.

[11] Mieder, W. (1989). American Proverbs: A Study of Texts and Contexts. New York: Peter Lang.

[12] Rokeach, M. (1973). The Nature of Human Values. New York: Free Pres.

[13] Samovar, L. A. et al. (2000). Communication between Cultures ( $\left.3^{\text {rd }}\right)$. Beijing: Foreign Language Teaching and Research Pres.

[14] Saussure, F. (1983). Course in General Linguistics (translated by Harris R.). London: Duckworth.

[15] Stevenson, B. (ed.) (1976). The Macmillan Book of Proverbs, Maxims, and Famous Phrases. New York: Macmillan.

[16] Tylor, E. B. (2005). Primitive Culture: Researches into the Development of Mythology, Philosophy, Religion, Language, Art, and Custom. Guilin: Guangxi Normal University Press.

[17] Ungerer, F. \& Schmid, H. J. (2001). An Introduction to Cognitive Linguistics. Beijing: Foreign Language Teaching and Research Press.

[18] Vice, S. (1997). Introducing Bakhtin. Manchester \& New York: Manchester University Press.

[19] Voloshinov, V. N. (1986). Marxism and the Philosophy of Language (translated by Marksizm). Massachusetts \& London: Harvard University Press.

[20] Watson, O. (ed.) (1976). Longman Modern English Dictionary. London: Longman.

[21] Webster, N. (ed.) (1979). Webster's Dictionary of the English Language, Unabridged. New York: Publishers International Press.

[22] Wen, Duanzheng. (2005). Chinese Lexicology. Beijing: The Commercial Press.

[23] Whiting, B. J. (1989). Modern Proverbs and Proverbial Sayings. Cambridge, Massachusetts \& London: Harvard University Press.

[24] Wilson, F. P. (ed.) (1982). The Oxford Dictionary of English Proverbs ( $\left.{ }^{\text {rd }}\right)$. Oxford: Oxford University Press.

Wen Zhao, (Han $\mathrm{Zu}$ ) 28, is a lecturer teaching English language in English department of Sichuan Agricultural University. He attained his MA degree of Foreign and Applied Linguistics in Sichuan University in China. He has interests in Cognitive Lingu istics and Semiotics. 